Proc. Indian Acad. Sci. (Earth Planet. Sci.), Vol. 98, No. 1, April 1989, pp. 71-89.

(C) Printed in India.

\title{
Active tectonics of the Himalaya
}

\author{
JAMES F NI \\ Departmeht of Physics, New Mexico State University, Las Cruces, NM 88003; USA
}

\begin{abstract}
The Himalayan mountains are a product of the collision between India and Eurasia which began in the Eocene. In the early stage of continental collision the development of a suture zone between two colliding plates took place. The continued convergence is accommodated along the suture zone and in the back-arc region. Further convergence results in intracrustal megathrust within the leading edge of the advancing Indian plate. In the Himalaya this stage is characterized by the intense uplift of the High Himalaya, the development of the Tibetan Plateau and the breaking-up of the central and eastern Asian continent. Although numerous models for the evolution of the Himalaya have been proposed, the available geological and geophysical data are consistent with an underthrusting model in which the Indian continental lithosphere underthrusts beneath the Himalaya and southern Tibet. Reflection profiles across the entire Himalaya and Tibet are needed to prove the existence of such underthrusting. Geodetic surveys across the High Himalaya are needed to determine the present state of the MCT as well as the rate of uplift and shortening within the Himalaya. Paleoseismicity studies are necessary to resolve the temporal and spatial patterns of major earthquake faulting along the segmented Himalayan mountains.
\end{abstract}

Keywords. Himalayan mountains; continental collision; earthquakes; active tectonics; tectonic setting; Main boundary thrust; Tethyan slab.

\section{Introduction}

The Himalaya is the largest mountain chain in the world. Accordingly, understanding the mechanics responsible for its formation and for its support must be two of the most important geological problems. Moreover, study of the active tectonics of the Himalayan mountain belt is important because such a region contains information that is unavailable in other, older mountain belts, but necessary in order to understand how mountain building takes place.

Early episodes in orogenic research (last quarter of the 18th and first half of the 19th centuries) were characterized by the interpretation that mountain belts are a result of vertical uplift. It was not until the late 19th century that the role of horizontal movements became more widely appreciated. The development of geosynclinal theory in the early 20th century to explain the prehistory of mountain belts and the subsequent horizontal shortening in orogeny as expressed by fold and nappe structures delayed a more accurate understanding of mountain building. As the concept of plate tectonics was developed during the 1960 s, numerous models for the evolution of the Himalaya were proposed. The past decade has included a transition from a focus on testing of the Himalayan collision models to research based more on observation. The models developed in the 1970 s and refined in the 1980s have provided the direction of investigation as deeper observations have been made possible by geophysical techniques. 
This review focuses on the deep crustal and uppermost mantle structures of the Himalaya, because these features reflect the mechanical processes that result in mountain building. The review also will discuss recent work on the Pakistan Himalaya.

\section{Collision models}

Early ideas about the architecture of the Himalaya assumed that the Himalayan Mountains rest on a rigid substratum that is similar to the rocks beneath the Indian Shield. However, geodetic measurements (plumb line) of Pratt (1855) showed that the observed deflection was much smaller than expected for a rigid model. Shortly following this experiment the concept of isostasy was born and a floating Himalayan range with a "crustal root" became the dominant geological thinking for the early twentieth century. With the improvement of gravity meters, numerous studies have shown that gravity measurements deviate from local isostatic equilibrium. This discovery suggested that the Himalaya is not completely supported by the buoyancy force; rather it is held up, at least in part, by an upward force. Searching for the origin of this force is essential to understanding the dynamics of mountain building.

The concept of underthrusting of one continental lithosphere beneath another as the cause of mountain building and plateau uplift was first proposed by Argand (1924). With the advent of the new global tectonics (e.g. Isacks et al 1968) a number of different mechanisms for the uplift of the Himalaya and Tibet have been developed. Dewey and Bird (1970) suggested that the Himalaya was formed solely by the collision of an Atlantic-type continental margin with the Asian continent bordered by a marginal trench. In their model they assumed that the buoyancy of the continental lithosphere prevents further subduction and they overlooked the possible significance of intracontinental thrusts. Powell and Conaghan (1973) pointed out that the geological history of the Himalaya does not agree with the simple continentcontinent collision model of Dewey and Bird (1970), because the collision itself did not directly produce the present-day Himalaya. Alternatively, Powell and Conaghan (1973, 19.75) and Powell (1979) proposed an "evolutionary" model (figure 1) invoking two phases of orogeny. In their model, the first phase is related to active Mesozoicearly Tertiary subduction zones along the present-day Indus-Tsangpo suture, analogous to the North American Cordilleras. This phase ended in the Eocene (e.g. Molnar and Tapponnier 1975; Tapponnier and Molnar 1977) when India collided with Asia. The Indus-Tsangpo suture is a direct result of this collision. The second phase involves formation of intracontinental fractures within the northern Indian margin during the Middle Tertiary and underthrusting of the Indian continent along this fracture from Miocene time to the present.

Since 1973, increasing amounts of data on the Himalaya and Tibet have become available and, consequently, many plate tectonic models have been proposed for the evolution of the Himalaya (e.g. LeFort 1975; Molnar et al 1977; Bird 1978; Seeber et al 1981; Chen and Molnar 1981; Barazangi and Ni 1982; Molnar and Chen 1982; Ni and Barazangi 1984; Molnar 1984). Among these models, much of the debate about the tectonics of the Himalaya is concerned with the nature of the Main Boundary Thrust (MBT) and Main Central Thrust (MCT). According to LeFort (1975), the Himalaya was formed by the imbrication of slices of India's northern margin. In his evolutionary model (figure 1), the MBT and MCT are assumed to be similar, but successive, 
A. La Fort 1975

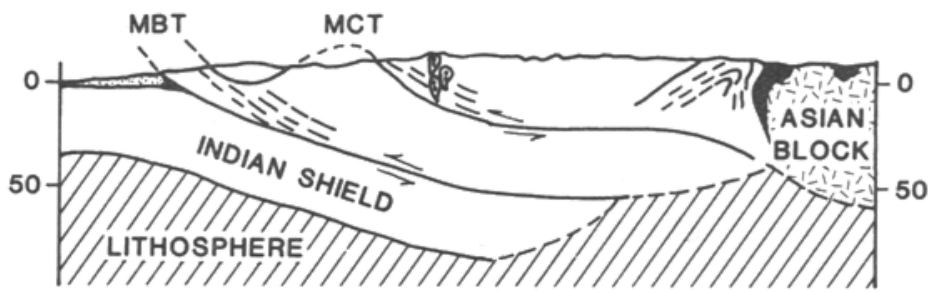

B. Powell 1979
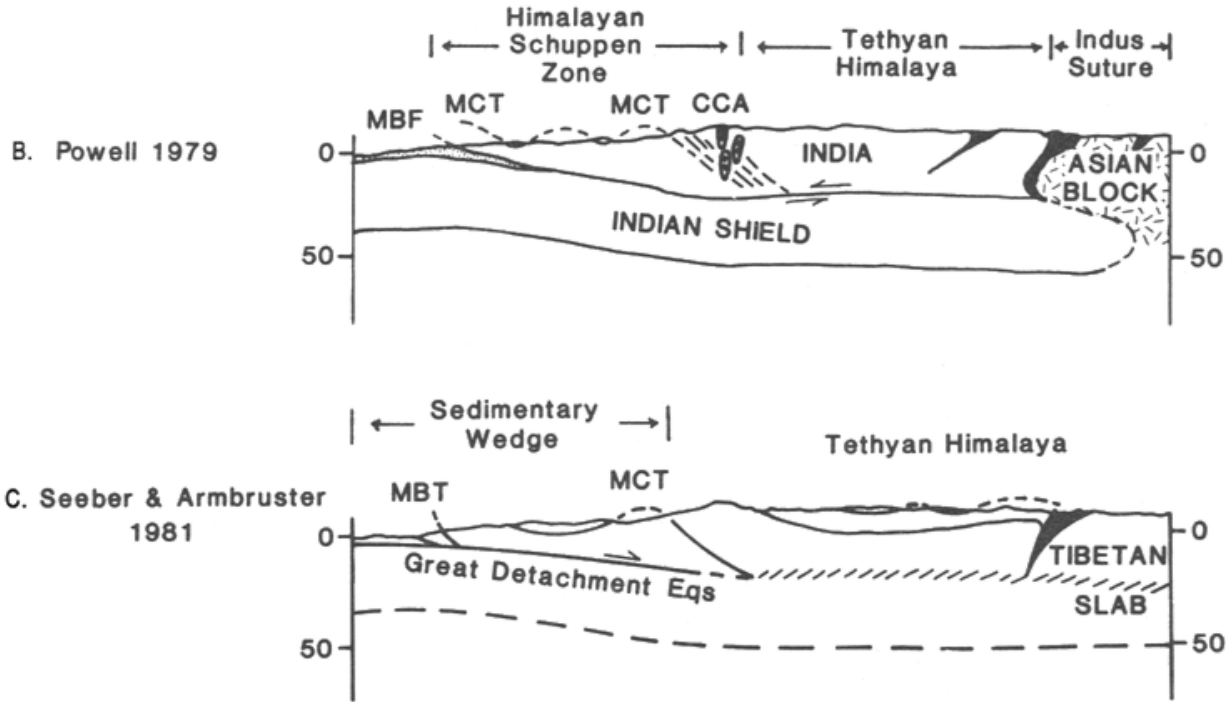

D. Burg \& Chen 1984
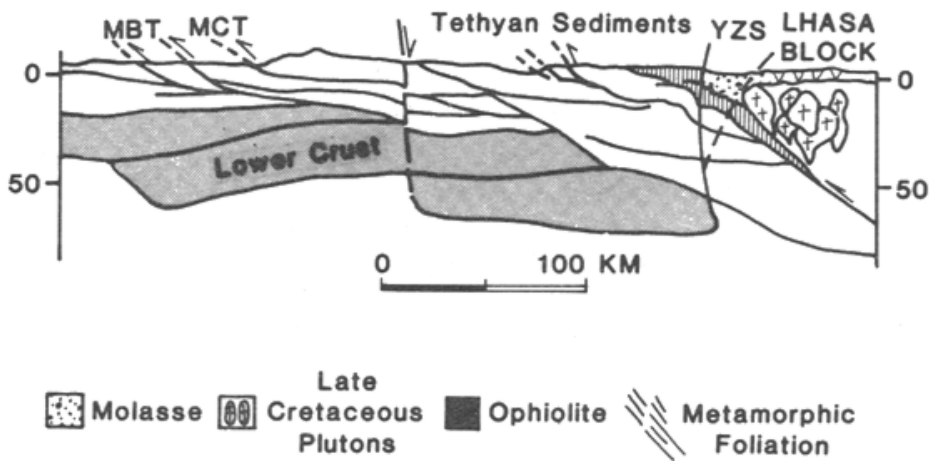

Figure 1. Comparison of tectonic models of the Himalaya. A. After La Fort (1975). The Himalaya was formed by imbrication of slices of India's northern margin. B. After Powell (1979). The MCT and MBT are fundamentally different structures in this model. C. After Seeber and Artnbruster (1981). All the elements in this model are active simultaneously and subduction proceeds without fundamental changes in the structure. This model was named the "steady-state" model. D. After Burg and Chen (1984). In their model, decoupling and thrusting, which separate lower and upper crustal layers, occur contemporaneously with each other.

tectonic thrusts. The southern thrust zone (i.e. the MBT) becomes the new boundary of the continental convergent zone, while the older thrust zone (i.e. the $\mathrm{MCT}$ ) becomes a less active or a dormant feature.

In contrast, Seeber and Armbruster (1981) proposed a "steady-state" model 
(figure 1) for the evolution of the Himalaya. This model requires that the MBT and MCT are contemporaneous features. Central to this model is a detachment (decollement) surface underlying the entire Himalaya. The detachment represents the upper surface of the underthrusting Indian plate. Seeber et al (1981) also postulated the presence of a Basement Thrust (BT) where the northerly and relatively steeply dipping MCT merges with the shallow dipping detachment surface at depth (see figure 11 of Seeber et al 1981). The BT zone represents the front of the overriding crystalline basement (analogous to a bulldozer blade), and it is along this front where the sedimentary rocks above the Indian Shield are scraped off.

A more complex model for the Himalaya has been proposed by Hirn et al (1984a) and Burg and Chen (1984) (figure 1). Their model is mostly based on the interpretation of recent reflection data in which a variation in the level of the Moho has been suggested. In their model, decoupling and thrusting, which separate lower and upper crustal layers, occur contemporaneously with each other. However, polarities of thrusting are opposite to each other (figure 1).

\section{Tectonic setting}

The hypotheses of the evolution of the Himalaya discussed above depend largely on understanding the evolution and structure of major tectonic features and their behaviour at depth. The following is a brief summary of the main structural characteristics of these features (figure 2).

\subsection{Indus-Tsangpo suture}

The Indus-Tsangpo suture (e.g. Gansser 1964, 1980; LeFort 1975) marks the northern limit of the Indian subcontinent following the late Cretaceous-early Tertiary closure of the Neo-Tethys. The suture is made up of imbricated melanges of flysch sediments, radiolarite, pillow lavas, volcanics, and basic and ultrabasic rocks that are cut by steep thrust faults (e.g. Stocklin 1980; Allegre et al 1984).

\subsection{Main central thrust (MCT)}

The MCT, at the base of the crystalline zone, (e.g. Gansser 1964) dips $30^{\circ}$ to $45^{\circ}$ northward, separating the Higher Himalaya from the Lesser Himalaya. The thrust is characterized by a zone of intense shearing; no master thrust surface is apparent (e.g. Valdiya 1980; Sinha-Roy 1982). An abrupt change in the style of structures, especially folding, and in the grade of metamorphism is the main manifestation of the presence of the MCT. The MCT appears to have developed since mid-Tertiary time, and there are some geological indications of minor recent movements along the MCT (e.g. Valdiya 1980; Stocklin 1980; Gansser 1982).

\subsection{Main boundary thrust (MCT)}

The MBT is a series of thrusts that separate the predominantly pre-Tertiary Lesser Himalaya sediments from the Tertiary Siwalick sedimentary belt (i.e. the SubHimalayas belt) (e.g. Wadia 1961; Fuchs 1975; Gansser 1964, 1977). The steep thrust 


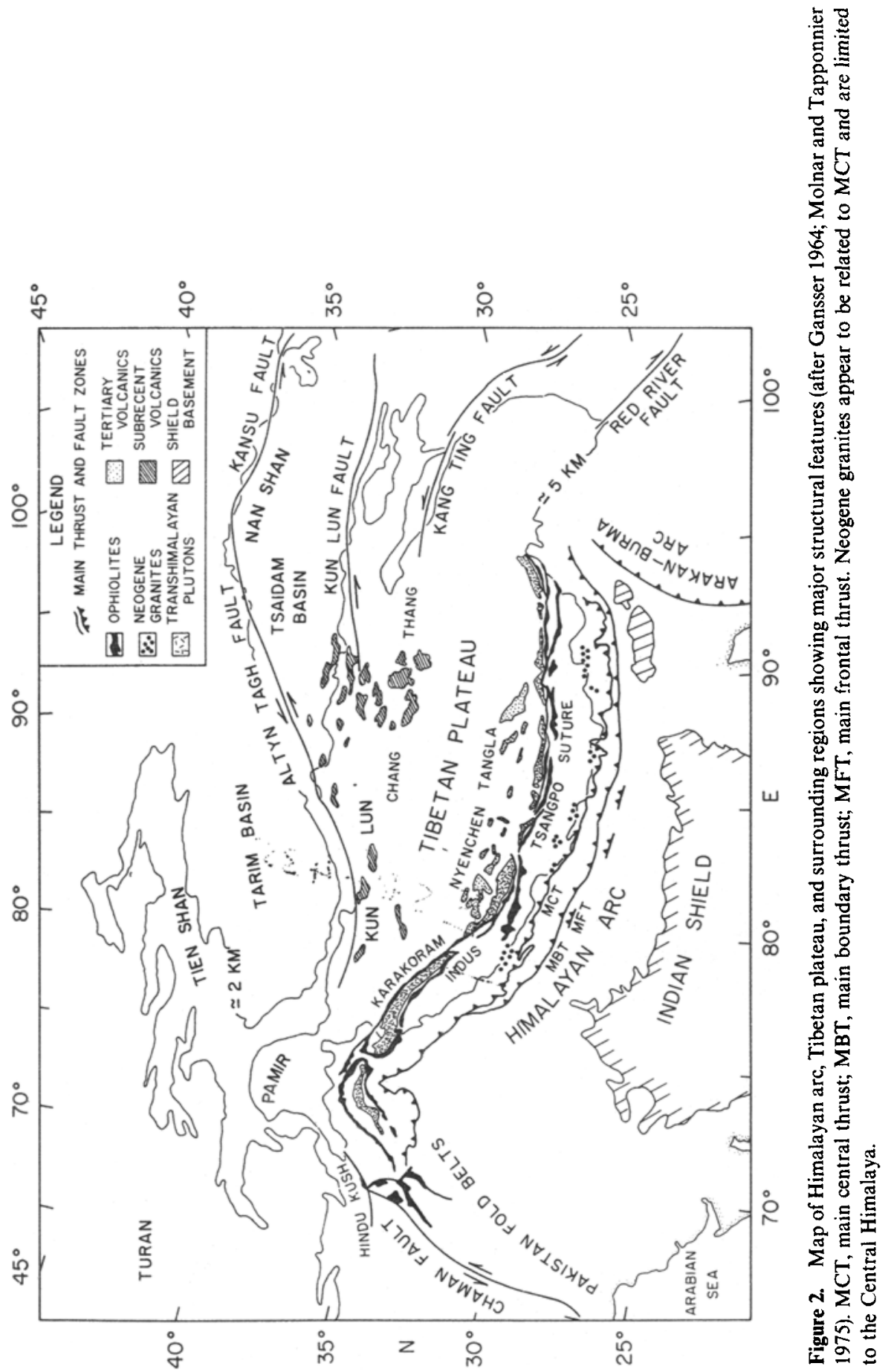


planes of the MBT at the surface gradually flatten out at depth (Valdiya 1980). The MBT has developed since Pliocene time, and abundant geological evidence shows that the thrust zone was active through the Pleistocene (e.g. Mathur and Evans 1964; LeFort 1975; Valdiya 1981).

\subsection{Tethyan slab}

The region between the MCT and the Indus-Tsangpo suture is composed of the Tethyan sedimentary zone in the north and the central crystalline zone in the south, and is often referred to as the Tethyan slab. The richly fossiliferous, platform-type sediments of this region (Paleozoic-Mesozoic age) are clearly of Gondwana affinities and represent the former Indian margin. Burg and Chen (1984) showed that the Tethyan slab consists of several thrust sheets with distinct stratigraphies, states of deformation and metamorphic grades. Crustal shortening of the northern Tethyan slab is produced by decoupling and thrusting of both upper and lower crustal layers (Burg and Chen 1984). As the result of continental collision the Tethyan sediments are also intruded by Tertiary leucogranite. The leucogranite, dated between 10-20 Ma, (LeFort 1975, 1981; Vidal 1978; Wang et al 1981) appears to have a certain stratigraphic and structural relationship when compared with the position of the MCT. First, the metamorphic isogrades run roughly parallel to the MCT for great distances (e.g. LeFort 1975). Second, the metamorphic isogrades are inverted in the upper level of the Lesser Himalaya. A high ${ }^{87} \mathrm{Sr} /{ }^{86} \mathrm{Sr}$ ratio (e.g. LeFort 1981; Wang et al 1981) of the leucogranite clearly indicates that it was derived from a crustal source, however, the source of heat remains an enigma.

\subsection{Normal faulting in the High Himalaya}

Burg et al (1984) indicate the existence of an east-west striking, gently north-dipping normal fault of regional extent in the High Himalaya. This normal fault zone separates the highly metamorphosed crystalline rock and a transitional zone from the overlying late Precambrian to Cambrian sedimentary sequence. A similar type of normal faulting has been observed in the Zanskar region of the western Himalaya (Herren 1987). Movement along the shallow-dipping normal fault is believed to be about $20 \mathrm{~km}$ and limited to the deformation of upper crust. Analysis of two-mica granite shows that normal faulting is coeval with the south-directed overthrusting along the MCT (Copeland et al 1987). Burchfiel and Royden (1985) suggest that the tensional stress induced by the difference in topography between the Indian foreland and the southern edge of the Tibetan Plateau is a possible cause for the extensional faulting parallel to the Himalayan ranges. At present there are little data on these normal faults. It appears that the normal faulting can be considered as an important effect superimposed on the north-south regional compression.

\subsection{Strike-slip faulting}

A secondary effect of the north-south shortening of the Himalaya is the pervasive strike-slip faulting throughout most of the Lesser Himalaya. Valdiya $(1976,1981)$ indicated that the strike-slip faults have right-laterally displaced the MBT by as much as $12 \mathrm{~km}$. Other examples of strike-slip faulting in the Nepal Himalaya have been reported by Nakata (1988). 


\section{Observational constraints}

\subsection{Earthquakes and fault plane solutions}

The Himalaya is seismically active. During the last decade not only have four great earthquakes $(M>8)$ occurred along the Himalaya, but also a large number of moderate-sized earthquakes. Local seismic networks are restricted to the western Himalaya and the Assam region. Therefore, earthquake hypocenters for the Himalayan events are based on teleseismic locations. Routine location procedures usually yield reasonably good locations with uncertainties not exceeding $20 \mathrm{~km}$. However, the focal depths of these events can have errors of as much as $50 \mathrm{~km}$. Recently developed techniques of synthetic body wave modelling of $\mathrm{P}$ and $\mathrm{SH}$ waves not only provide a better constraint on the orientation of nodal planes but also provide good depth control for shallow events to $\pm 3 \mathrm{~km}$. Using this technique Baranowski et al (1984) and $\mathrm{Ni}$ and Barazangi (1984) showed that the moderate sized thrust-type events in the central and eastern Himalaya lie between 10 and $15 \mathrm{~km}$ depth. Based on a qualitative selection criteria, Ni and Barazangi (1984) showed that the better located epicenters are concentrated in a narrow zone, about $50 \mathrm{~km}$ wide, lying just south of the MCT (figure 3). Focal mechanisms obtained from forward waveform modelling indicate thrust faulting with one nodal plane dipping gently $\left(<30^{\circ}\right)$ north or northeast beneath the Himalaya and the other nodal plane dipping steeply southward (figure 3 ). It is generally accepted that the shallow north-dipping nodal planes are the fault planes (figures 3,4).

Projection of all reliable thrust-type events along the Himalayan arc into a single cross-section reveals that these events define a simple planar zone, having an apparent northward dip of about $15^{\circ}$ (figure 4). This shallow northward dipping zone has been interpreted as a part of the master detachment of the Himalaya (Ni and Barazangi 1984).

Baranowski et al (1984) suggested that the orientation of slip vectors is approximately perpendicular to the Himalayan range. Their method of constraining the direction of slips was primarily based on forward modelling of $P$ waves (SH waves were used for only a few earthquakes). The orientation of slip vectors is approximately perpendicular to the Himalayan range. Thus, the gravitational spreading of the overriding Himalaya and Tibet contributes greatly to the deformation of the Himalaya. Teleseismic earthquake data indicate that the MBT, rather than the MCT, is currently the active feature of the Himalayan arc. It is most probable that the great Himalayan events occur along the same detachment surface as defined by the moderate-sized thrust-type events (figure 5).

\section{$4.2 P_{n}$ and $S_{n}$ wave propagation beneath the Himalaya}

Variations in $P_{n}$ and $S_{n}$ velocities can be used to indicate regional differences in the physical properties of the uppermost mantle. Examples of high $P_{n}$ velocities $(8.2-8.4 \mathrm{~km} / \mathrm{s})$ and $S_{n}$ velocities $(4.7 \mathrm{~km} / \mathrm{s})$ have been reported for a variety of continental shield regions (Brune and Dorman 1963; Bath 1966; Huestis et al 1973), whereas low $P_{n}$ velocities $(7.7-7.8 \mathrm{~km} / \mathrm{s})$ and $S_{n}$ velocities $(4.4-4.5 \mathrm{~km} / \mathrm{s})$ characterize, for example, most of the Basin and Range province in which the lithosphere is thin and heat flow values are high (Eaton 1980).

$P_{n}$ and $S_{n}$ travel times from earthquakes in the Himalaya to the World Wide 


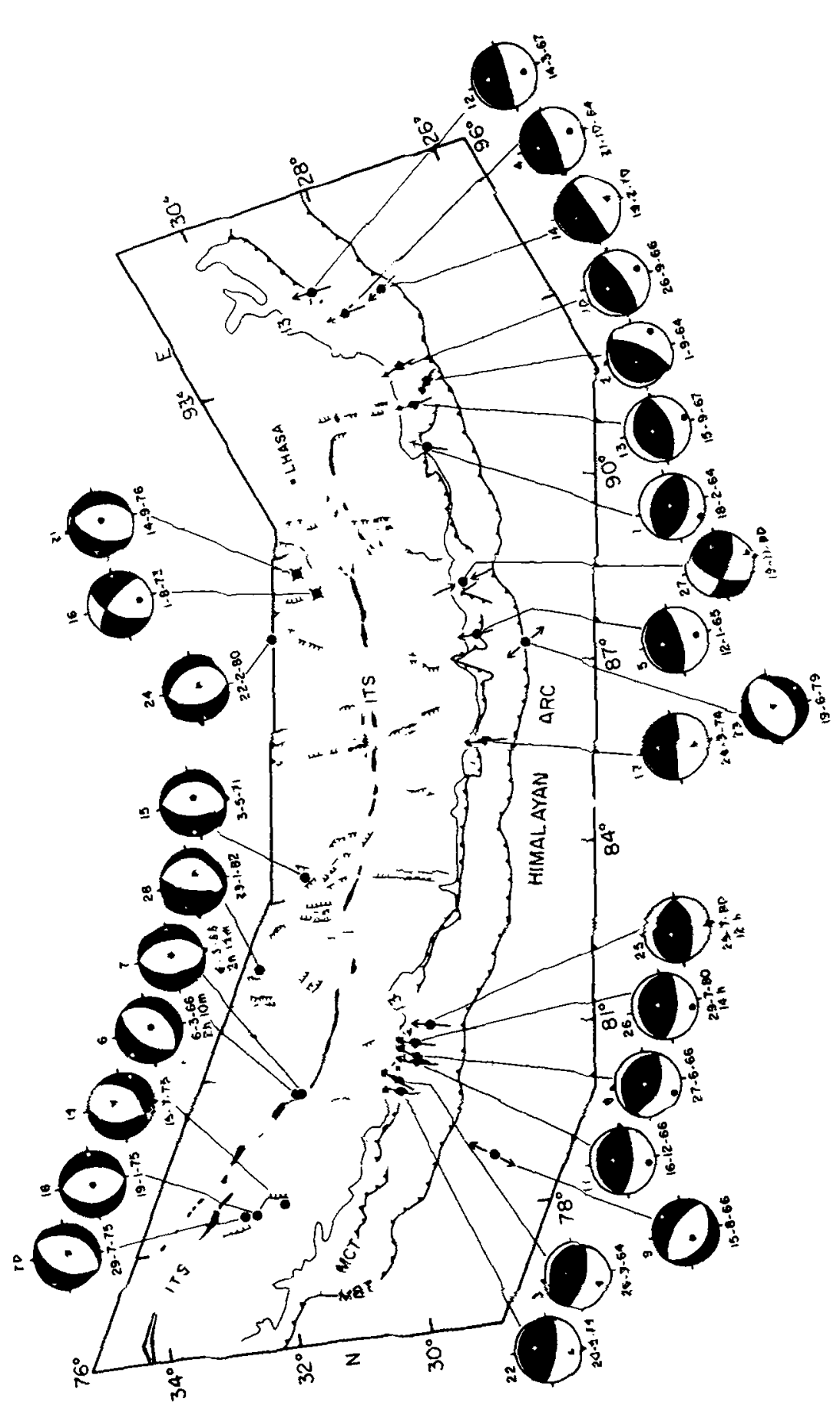

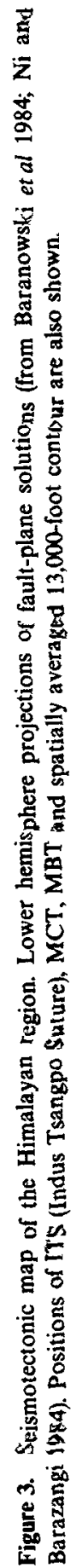



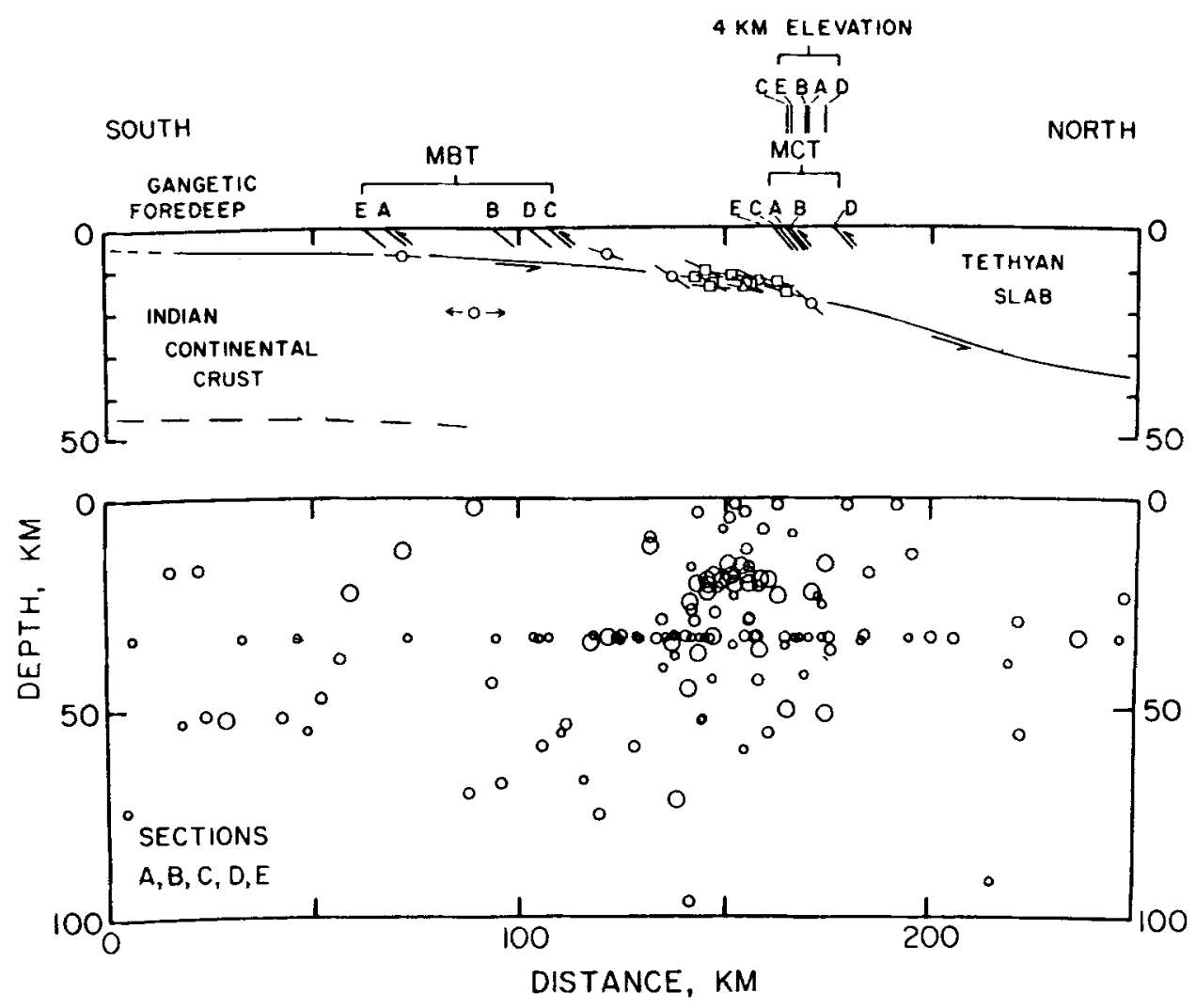

Figure 4. A composite cross-section using the MCT and the 4-km elevation contour as a reference for projection. Bottom section shows ISC hypocenters. The larger the open circle the better the epicenter location. Notice that the majority of earthquakes are located south of the MCT In the top section the projected low-angle nodal planes for thrust-type focal mechanisms are shown as line segments drawn across the accurately located depths of hypocenters. From Ni and Barazangi (1984).

Standard Seismograph Network (WWSSN) stations at northern Afghanistan, India, and to the local network at northern Pakistan, have been used to resolve the uppermost mantle $P$ and $S$ wave velocities. For paths along the Himalaya to the Tarbela Dam network in northern Pakistan, Menke and Jacob (1976) obtained $P_{n}$ and $S_{n}$ velocities of $8.5 \pm 3.5 \mathrm{~km} / \mathrm{s}$ and $5.00 \pm 2.0 \mathrm{~km} / \mathrm{s}$ respectively. With WWSSN data, Ni and Barazangi (1983) obtained $8.45 \pm 0.08 \mathrm{~km} / \mathrm{s}$ and $4.74 \pm 0.5 \mathrm{~km} / \mathrm{s}$ (figure 6), which are similar to the corresponding $P_{n}$ and $S_{n}$ velocities for the uppermost mantle beneath the Indian Shield and Southern Tibet. The crustal and uppermost mantle velocity structure of the Himalaya derived from body waves (Ni and Barazangi 1983) is consistent with that obtained from surface wave dispersion (Gupta and Narain 1967). The high $P_{n}$ and $S_{n}$ velocities indicate that the uppermost mantle structure beneath the Himalaya is not significantly different from that of India and southern Tibet and is consistent with a model in which the Indian continental lithosphere is being underthrust beneath the Himalaya and southern Tibet. 


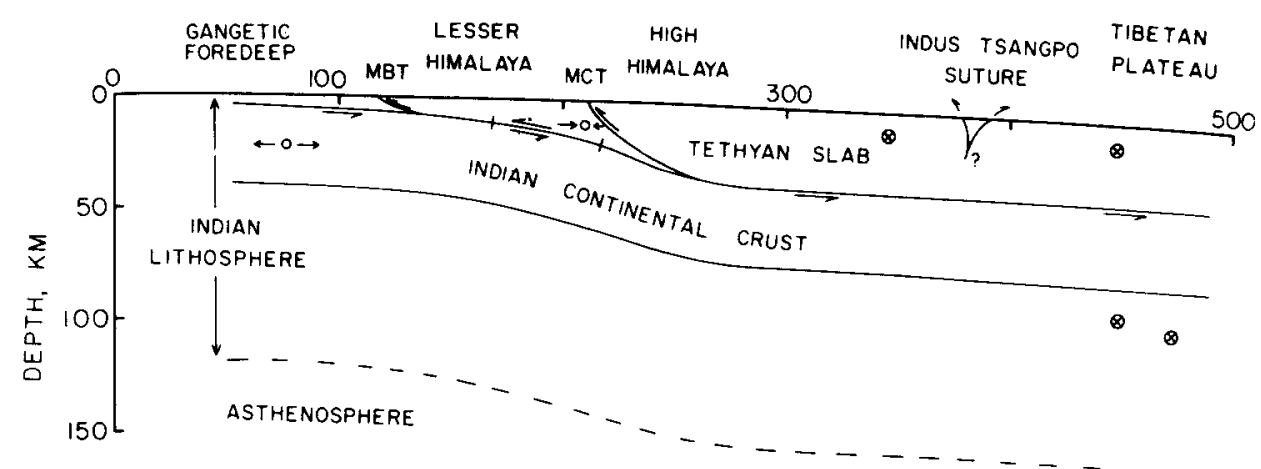

Figure 5. A schematic cross-section of the present geometries of converging plates in the Himalaya-Tibetan region. Events with normal-type focal mechanisms located in the shallow crust and uppermost mantle of Tibet are shown as open circles with crosses. All Himalayan thrust-type events can be interpreted most simply to define a part of the detachment between the underthrusting Indian plate and the upper Himalayan crustal blocks.

HIMALAYA MTS.
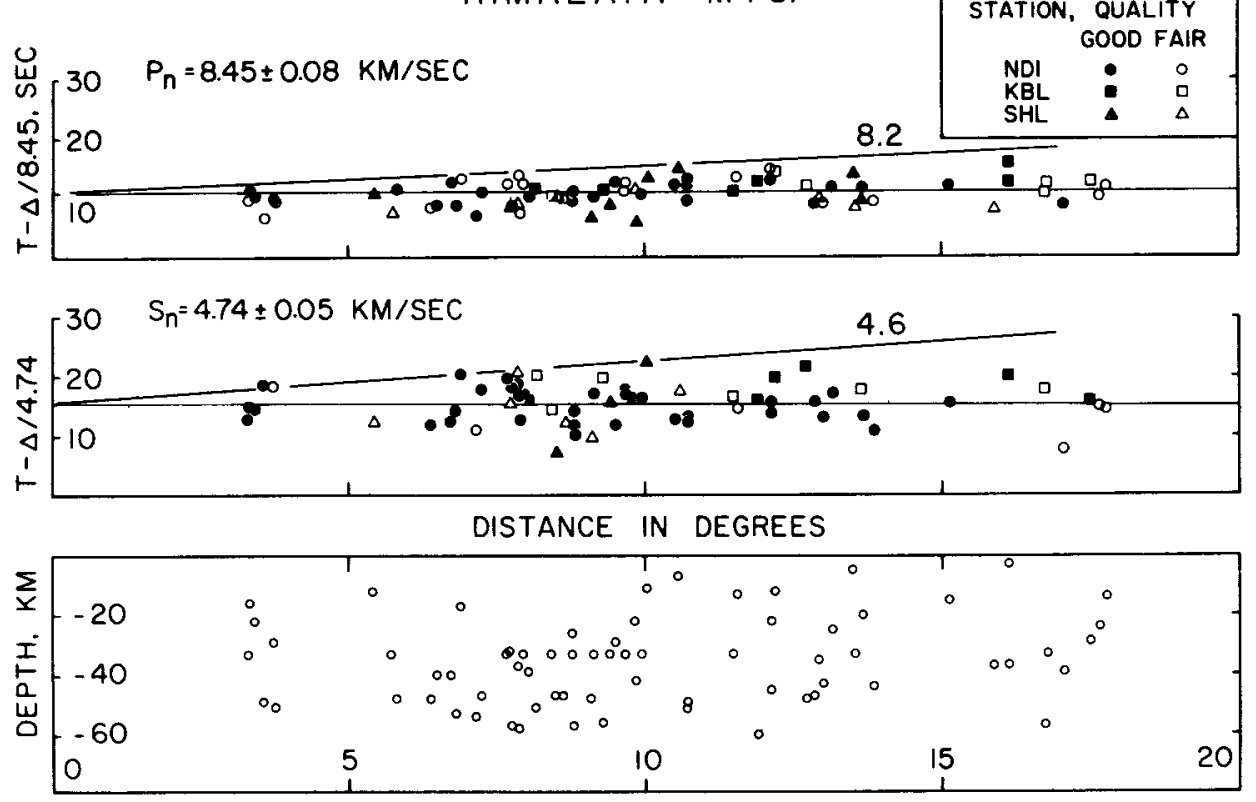

Figure 6. Reduced travel-time plots of $P_{n}$ and $S_{n}$ data recorded at station NDI, KBL and SHL. At least $50 \%$ of the propagation paths are within the Tibetan Plateau. The bottom plot shows ISC hypocentral depth vs epicentral distance for events used in the above travel-time plots. 


\subsection{Refraction profiles and wide-angle reflections beneath the Himalaya}

Significant information on the velocity structure of the Himalaya comes from: (i) an unreversed profile that crosses the western Himalaya (Kaila et al 1978; Beloussov et al 1980); and (ii) wide-angle reflection profiles recorded in Nepal (Hirn and Sapin 1984; Hirn et al 1984a, b).

Two spreads, one $6 \mathrm{~km}$ long and the other $11 \mathrm{~km}$ long, located near the Srinagar region of the Kashmir Himalaya recorded shots fired in Pakistan and USSR. These data recorded clear reflection from the Moho. Kaila et al (1978) showed that the Moho is at a depth of about $45 \mathrm{~km}$ near Sopur, dips to $54 \mathrm{~km}$ in the region of Wular. Lake and continues to deepen further toward the north. Such geometry indicates a moderate, $15^{\circ}$ to $20^{\circ}$ northwesterly dip of the Moho. The dip of the Moho could be an overestimate because the profile is not reversed.

Wide-angle reflection data in the Tethyan and High Himalaya were collected by Hirn and his colleagues. Seismograms recorded at Arun valley and Kathmandu valley from shots in southern Tibet showed two clear phases separated by about $2 \mathrm{~s}$. The later phases were interpreted as a $P_{m} P$ (Moho) reflection from $75 \mathrm{~km}$ depth (Lepine et al 1984). The earlier phase was attributed to reflection from the top surface of the underthrusting Indian Plate (Hirn and Sapin 1984). Although Lepine et al (1984) suggested that a step in the Moho existed somewhere just north of the High Himalaya, Molnar (1988) indicated that six seismograms are insufficient to constrain the geometry of the Moho.

Most of the evidence supporting a southward dipping Moho beneath the Himalaya is from a fan profile constructed with seismograms at distances of 170 to $300 \mathrm{~km}$ recorded in Nepal and southern Tibet (figure 7). The arrival times from the first strong signals recorded by seven stations located north of the High Himalaya (figure 3 of Hirn et al 1984a) show a southward dipping reflector from 45 to $50 \mathrm{~km}$ depth. Hirn et al (1984a) interpreted this reflector as representing a southward dipping Moho. Molnar (1988) argued that this reflector can be associated with reflection from an interface within the crust. Moreover, he pointed out that reflections in the fan profile are consistent with a Moho increasing smoothly from 50 to $55 \mathrm{~km}$ beneath the Great Himalaya to about $70 \mathrm{~km}$ in the southern Tethyan Himalaya.

\subsection{Gravity anomalies across the Himalaya}

Gravity anomalies in the Himalaya place constraints on the deep structures and the dynamics of mountain building. In the Himalaya large Bouguer anomalies become increasingly negative as the elevation increases, their values reach about $-400 \mathrm{mGals}$ over the Great Himalaya (Marussi 1964; Quershy 1969; Quershy and Warsi 1980; Verma and Prasad 1987). This northward decrease in Bouguer anomalies is interpreted to indicate some sort of isostatic compensation in the Himalaya. However, large negative isostatic anomalies ( $-100 \mathrm{mGals})$ over the Ganga Basin and ( + $80 \mathrm{mGals})$ in the High Himalaya indicate deviation from local isostatic compensation (e.g. Warsi and Molnar 1977; Lyon-Caen and Molnar 1983). The apparent causes of this deviation from isostatic equilibrium are the focus of recent studies (LyonCaen and Molnar 1983, 1985). Negative isostatic anomaly over the Ganga Basin can be explained, at least in part, by the several kilometers of low density upper Cenozoic sediments. Positive isostatic anomaly over large parts of the High Himalaya could be a result of thickening of a basaltic layer in the lower crust (Quershy and Warsi 1980). 


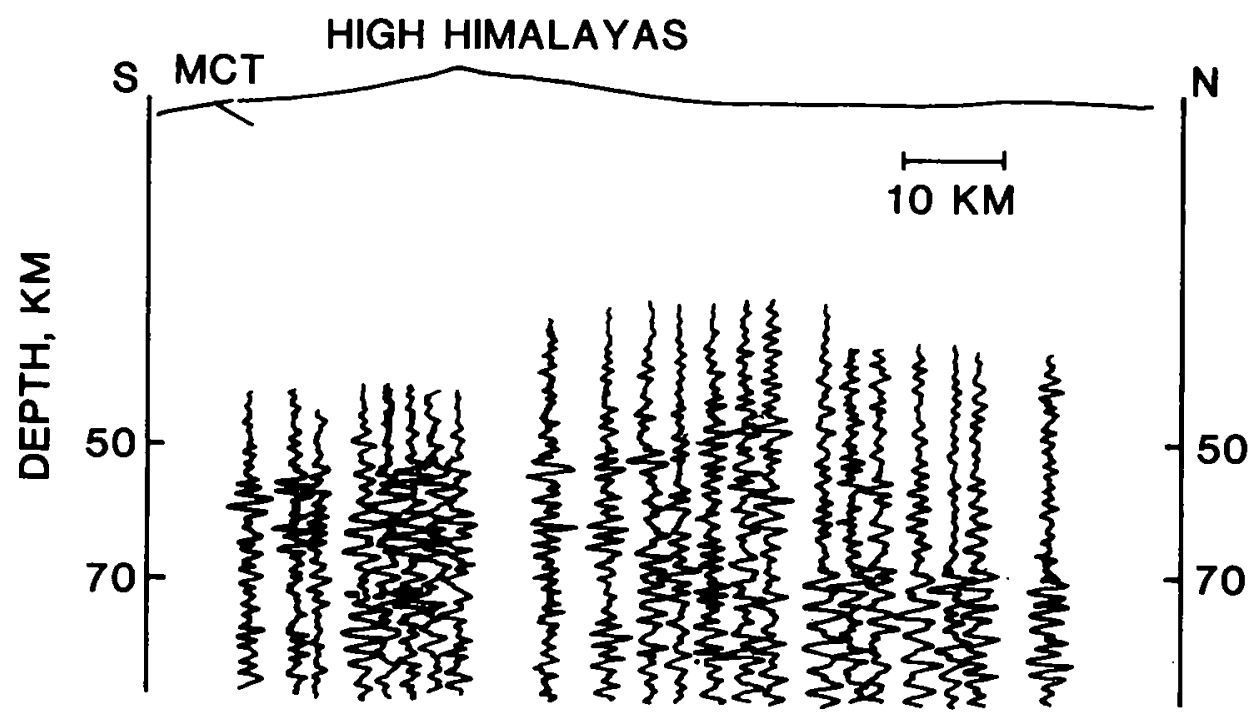

Figure 7. A north-south fan-profile across the Greater Himalaya, from Hirn et al (1984a). Reflection times are corrected to a constant offset of $200 \mathrm{~km}$. Reflections from about $70 \mathrm{~km}$ on the north and from about $55 \mathrm{~km}$ on the south are quite clear. Northward shallowing reflectors to depths of 50 to $45 \mathrm{~km}$ are seen on the middle traces. Note strong signals that follow these mid-crust reflectors from $65 \mathrm{~km}$ (9th and 10 th traces) to about $75 \mathrm{~km}$ on the 14th and 15 th traces. Thus, the wide angle reflection data are consistent with a northward dipping Moho from $55 \mathrm{~km}$ on the southern to $75 \mathrm{~km}$ on the northern Greater Himalaya.

Deficiency and excessive distribution of mass in the Himalaya must be supported by stress differences within the lithosphere and mantle. Thus, gravity anomalies in the Himalaya can be used to examine how the mountains are supported. In a simple elastic flexure model where the Indian lithosphere extends to the Indus-Tsangpo suture zone, the overburden is too great to depress the Ganga Basin deeper than observed, and the calculated gravity anomalies are much too negative (Lyon-Caen and Molnar 1983). Therefore, a simple flexure model cannot account for the gravity anomalies across the Himalaya.

The Indian lithosphere underthrusts beneath the Ganga Basin and Lesser Himalaya at a shallower angle than beneath the High Himalaya implying the Moho also has different dips. Recognizing this, Lyon-Caen and Molnar (1985) computed Bouguer gravity anomalies across the Himalaya using an elastic plate model with different flexure rigidity. Their calculations indicate that the load of the mountain is still too great to yield gravity anomalies over the Lesser Himalaya and Ganga Basin that are comparable with the observed values. A moment must be applied to the end of the elastic plate to properly support the Himalayan mountains. This moment can be related to either a horizontal force or a vertical force. Lyon-Caen and Molnar (1985) ruled out the horizontal force because it must have an excess horizontal compressive stress of at least $330 \mathrm{MPa}$. On the other hand, the vertical force can be related to phase change of the lower crustal material in the underthrusted Indian lithosphere and is more plausible.

In our opinion, analysis of gravity data explains the broad features of the Moho configuration that are consistent with a smoothly increasing Moho from $38 \mathrm{~km}$ 
beneath the Ganga Basin to about $55 \mathrm{~km}$ beneath the High Himalaya. Mountain building involves processes not only confined in the lithosphere but also in the upper mantle. The nature of the forces that support the excess weight of the mountain remain to be discovered.

\section{Pakistan Himalaya}

Information about the geometry of the underthrusting Indian plate within the Pakistan Himalayan foreland and fold-and-thrust belt has been reported by Lillie et al (1987). Based on the interpretation of oil company reflection data they showed that beneath a salt detachment, the Indian crystalline basement dips gently northward from about $1^{\circ}$ beneath the Salt range to about $4^{\circ}$ beneath the northern Potwar Plateau (figure 8). Their results confirm earlier interpretations that detachment lies within an Eocambrian evaporite sequence. The extent of this detachment and the geometry of the Indian plate farther north beneath the Peshawar basin are not clear.

Based on an analysis of local seismicity data Seeber and Armbruster (1979) showed two northwesterly trending basement features, the Hazara Lower Seismic Zone (HLSZ) and the Indus-Kohistan Seismic Zone (IKSZ) (figure 9). They interpreted these features as buried extensions of the northwesterly trending Himalayan thrust faults beyond their surface termination at the western Himalayan Syntaxis. The IKSZ, the more active of the two seismic zones, is associated with underthrusting toward the northeast (Seeber and Armbruster 1979). The HLSZ defines a steeply dipping basement fault which may merge southward with a shallow dipping surface of detachment between the basement and the sedimentary rocks of the Salt Range. Proving such a relation, however, requires that one knows the deep structures beneath this region.

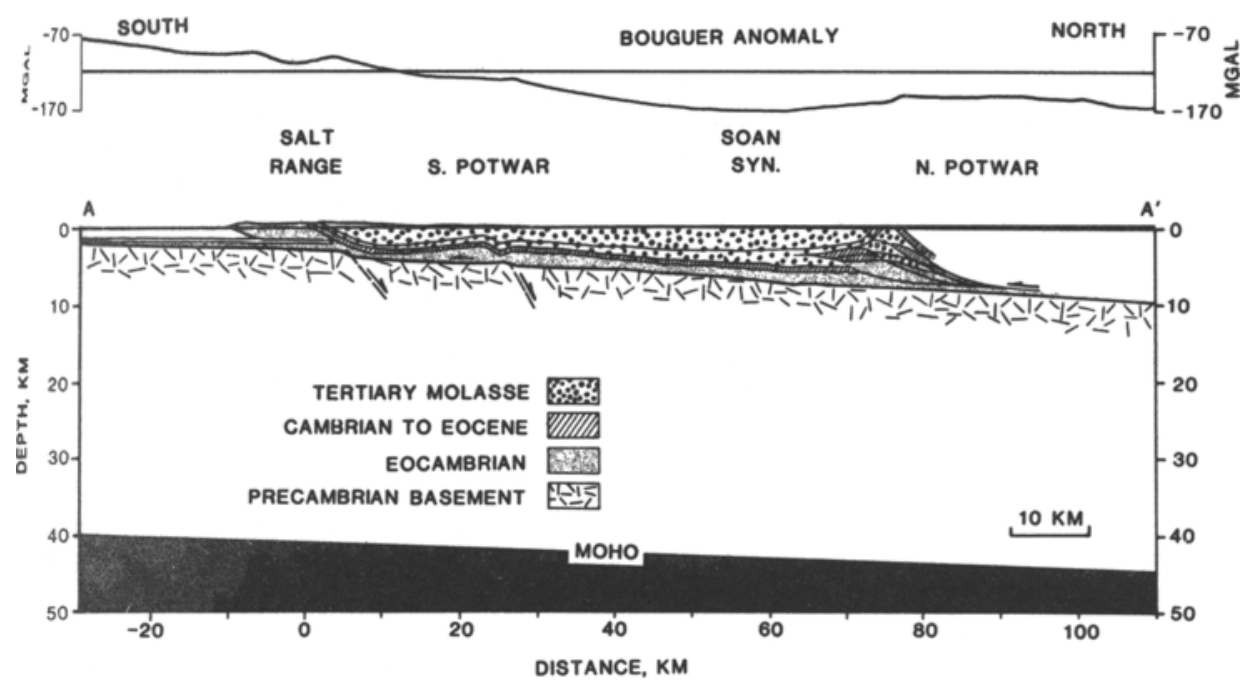

Figure 8. Structural cross-section and Bouguer gravity profile of northern Jhelum Plain, Salt Range and central Potwar Plateau, from Lillie et al (1987). The gradient in the Bouguer gravity in this region is about $1 \mathrm{mgal} / \mathrm{km}$ and is similar to that of the Indo-Gangetic Plain. 


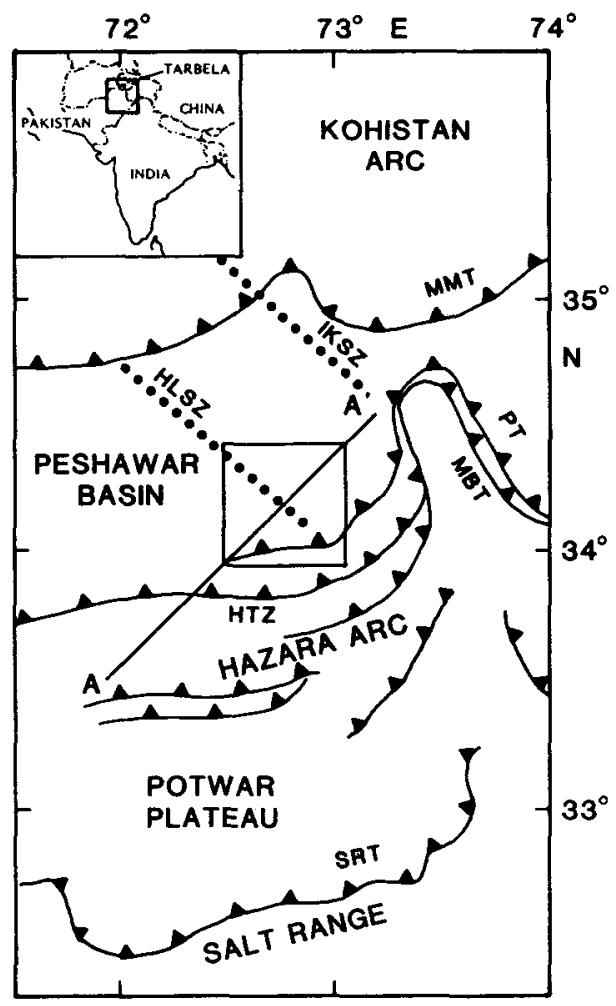

Figure 9. Simplified tectonic map of the western Himalayan syntaxis region. MBT, main boundary thrust; MMT, main mantle thrust; HTZ, Hazara thrust zone; PT, Panyal thrust; SRT, salt range thrust; HLSZ, Hazara lower seismic zone; IKSZ, Indus-Kohistan seismic zone.

A recent study (Ibenbrahim et al 1987) of the three-dimensional $P$ wave velocity structure beneath the northern Hazara thrust zone and the eastern Peshawar basin from inversion of $P$ wave travel time data produced by the Tarbela Dam array indicates that the $6.2 \mathrm{~km} / \mathrm{s}$ velocity surface dips northerly from about $13 \mathrm{~km}$ beneath the Hazara thrust zone (equivalent of MBT of the central Himalaya) to $17 \mathrm{~km}$ beneath the northern Peshawar basin. This surface has an apparent dip of about $8^{\circ}$ and is interpreted as the top surface of the underthrusting Indian Plate. This result incorporated with observations from the foreland (e.g. Farah et al 1977; Yeats and Hussain 1987; Lille et al 1987) is used to illustrate the geometry of the underthrusting Indian lithosphere in the Pakistan Himalaya. Beneath the Salt Range and Potwar Plateau the crystalline basement of the Indian Shield dips smoothly northward from about $1^{\circ}$ to about $4^{\circ}$. The detachment extends farther north beneath the Peshawar basin with an increased slope of $5^{\circ}-10^{\circ}$ (figure 10). The relocated hypocenters of shallow crustal events cluster at $11-14 \mathrm{~km}$ depth and are associated with the activity in the interplate seismic zone beneath the Peshawar basin. A steeper dip of the detachment is consistent with the mechanical thrusting model in which shale or other incompetent materials rather than evaporite form the zone of decollement (Davis et al 1983). Thus, an important implication of the steeper underthrusting of the Indian plate beneath the Peshawar basin is that this portion of the detachment appears to involve no salt and is capable of producing great earthquakes. 

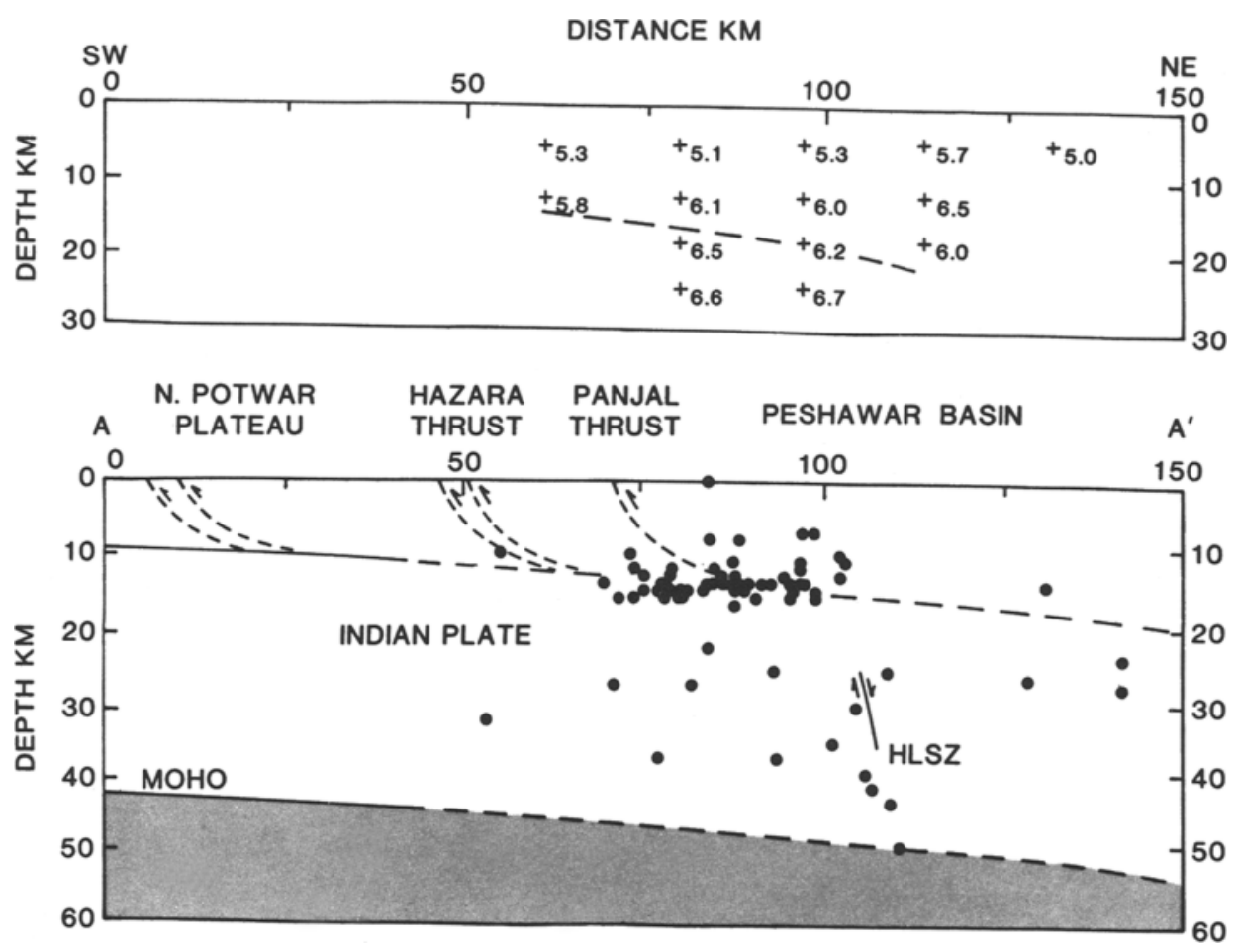

Figure 10. Structure cross-section ( $\mathrm{AA}^{\prime}$ in figure 9) shows that the gently dipping Indian plate beneath the Peshawar Basin correlates with the $6.2 \mathrm{~km} / \mathrm{s} P$-wave velocity contour. From Ibenbrahim et al (1987).

\section{Rates of uplift of the Himalaya}

It has been suggested by many authors that the uplift of the Himalaya occurred during recent geological time, especially during Quaternary and Holocene time (Wadia 1979; Zeitler et al 1982; Zeitler 1985; Coward et al 1987). A repeated levelling profile across the Himalayan frontal zone indicates as much as $6 \mathrm{~mm} / \mathrm{yr}$ of uplift in a 12-year period of the front with respect to the Ganga Basin (Chugh 1974; Molnar et al 1977). Although the levelling data suggest very rapid uplift, lower rates have been given when longer durations are considered.

Uplift rates using fission track methods imply movements of about $1 \mathrm{~mm} / \mathrm{yr}$ or less in the western Himalaya. However, higher rates of $7 \mathrm{~mm} / \mathrm{yr}$ have been reported for the Nanga Parbat-Haramosh region (Zeitler 1985). The increased uplift around the Nanga Parbat-Haramosh massif represents the culmination of Nanga Parbat Gneiss. Several millimeters per year uplift rates in the Higher Himalaya have been inferred from pollen and spores imbedded in the Quaternary sediments (e.g. Xu 1981). Table 1 gives estimates of uplift rates for the Himalaya. These uplift data indicate that rapid and recent uplift applies only to the region in which it is observed and does not suggest that recent uplift is at an accelerating rate. 
Table 1. Uplift rates of the Himalayan mountains.

\begin{tabular}{lll}
\hline Uplift rates (mm) & Method of determination & Source \\
\hline $0-1$ to $4 \cdot 5$ & Fission-track dating & Zeitler (1985) \\
$0-6$ to $0-8$ & Fission-track dating & Mehta (1980) \\
10 to $1 \cdot 4$ & River profiles & Seeber and Gornitz (1983) \\
2 & Bengal fan deposition & Curray and Moore (1971) \\
$0-1$ to 1 & River terraces & Iwata et al (1984) \\
1.2 to $1 \cdot 5$ & Levelling of river terraces & Iwata (1987) \\
6 & Second order levelling & Chugh (1974) \\
5 to 12 & Flexural modelling & Lyon-Caen and Molnar (1983) \\
\hline
\end{tabular}

\section{Summary}

The Himalaya is a product of the collision between India and Eurasia which began in the Eocene. In the earlier stage of continental collision the development of a suture zone between two colliding plates took place. A modern analogue of this stage may be the collision between the northern Australian continental margin and the Banda arc in the Timor island region. The continued convergence is accommodated along the suture zone and in the back-arc region. The Zagros represents an example of this stage. Further convergence results in intracrustal megathrust within the leading edge of the advancing Indian plate. In the Himalaya this stage is characterized by intense uplift of the High Himalaya and the development of the Tibetan Plateau in the backarc region. The tectonics of the modern Himalaya can be best explained by the model of $\mathrm{Ni}$ and Barazangi (1984). In this model (figure 5), the southern edge of the High Himalaya is likened to a curved bulldozer blade that scrapes most sediments from the Indian crust, and underthrusting proceeds without fundamental changes in the major structure.

Geological and geophysical constraints presented in this review are still insufficient to tightly constrain models outlined in the earlier section. Reflection profiles across the entire Himalaya and Tibet are needed to better resolve the deep crustal structures. Dense seismic and geodetic networks in the High Himalaya are needed to resolve the seismogenic nature of the MCT and the detailed structures. Initiation of paleoseimicity studies is necessary to resolve the temporal and spatial patterns of major earthquake faulting along the Himalaya.

\section{References}

Allegre C J et al 1984 Structure and evolution of the Himalaya-Tibet orogenic belt; Nature (London) 307 $17-22$

Argand E 1924 La Tectonique de l'Asie; Int. Geol. Congr. Rep. Sess. 131 170-732

Baranowski J, Armbruster J, Seeber L and Molnar P 1984 Focal depths and fault plane solutions of earthquakes and active tectonics of the Himalaya; J. Geophys. Res. 89 6918-6928

Barazangi $M$ and Ni $J 1982$ Velocities and propagation characteristics of $P_{n}$ and $S_{n}$ beneath the Himalayan arc and Tibetan Plateau: possible evidence for underthrusting of the Indian continental lithosphere beneath Tibet; Geology 10 179-185

Bath M 1966 Propagation of $S_{n}$ and $P_{n}$ to teleseismic distances; Pure Appl. Geophys. 64 19-30

Beloussov V V, Belyaevsky N A, Borisov A A, Volvovsky B S, Bolkovsky I S, Resvoy D P, Tal-Virsky B B, 
Kharmabeav I Kh, Kaila K L, Narain H, Marussi A and Finetti J 1980 Structure of the lithosphere along deep seismic sounding profile: Tian Shan-Pamirs-Karakorum-Himalayas; Tectonophysics 70 193-221

Bird P 1978 Initiation of intra-continental subduction in the Himalaya; J. Geophys. Res $834975-4987$

Brune J and Dorman J 1963 Seismic waves and earth's structure in the Canadian Shield; Bull. Seismol. Soc. Am. 43 167-210

Burchfiel B C and Royden L H 1985 North-south extension within the convergent Himalayan region; Geology 13 679-682

Burg J P and Chen G M 1984 Tectonics and structural zonation of sourthern Tibet, China; Nature (London) 331 219-223

Burg J P, Brunel M, Gapais D, Chen G M and Liu G H 1984 Deformation of leucogranites of the crystalline main central sheet in southern Tibet (China); J. Struct. Geol. 6 535-542

Chen W-P and Molnar P 1981 Constraints on the seismic wave velocity structure beneath the Tibetan Plateau and their tectonic implications; J. Geophys. Res. $865937-5962$

Chugh R S 1974 Study of recent crustal movements in India and future programs; paper presented at the International Symposium on Recent Crustal Movements, Zurich

Copeland P, Harrison T M, Parrish R, Burchfiel B C, Hodges K and Kidd W S F 1987 Constraints on the age of normal faulting, north face of Mt. Everest: Implication for Oligo-Miocene uplift; EOS Trans. Am. Geophys. Union 681444

Coward M P, Butler W H, Khan M A and Knipe R J 1987 The tectonic history of Kohistan arc and its implications for Himalayan structure; J. Geol. Soc. London 144 377-391

Curray J R and Moore D G 1971 Growth of the Bengal deep-sea fan and denudation in the Himalayas; Bull. Geol. Soc. Am. 82 563-572

Davis D M, Suppe J and Dahlen F A 1983 Mechanics of fold-and-thrust belts and accretionary wedges; $J$. Geophys. Res. 88 1153-1172

Dewey J F and Bird J M 1970 Mountain belts and the new global tectonics; J. Geophys. Res. 75 2625-2647

Eaton G P 1980 Geophysical and geological characteristics of the crust of the Basin and Range province, in Continental tectonics (ed.) Geophysics Study Committee (Washington DC: National Acad. Sci.) pp. 96-113

Farah A, Mirza M A, Ahman M A and Butt M H 1977 Gravity field of the buried shield in the Punjab plain, Pakistan; Geol. Soc. Am. Bull. 88 1147-1155

Fuchs G R 1975 Contribution to the geology of the northwestern Himalaya; Abh. Geol. B A 32 1-59

Gansser A 1964 The Geology of the Himalaya (London, New York, Sydney: Interscience Publishers) p. 289

Gansser A 1977 The great suture zone between Himalaya and Tibet: a preliminary account. In Colloq. Int. 268, Ecologie et géologiè de l'Himalaya, Paris 1976, ed. Cent. Natl. Rech. Sci. Vol. Sci. de la Ture, 181-191

Gansser A 1980 The significance of the Himalayan suture zone; Tectonophysics 62 181-191

Gansser A 1982 The morphogenic phase of mountain building. In Mountain building processes (ed.) K J Hsu (London: Academic Press) pp. 221-228

Gupta H K and Narain H 1967 Crustal structure of the Himalayan and Tibet Plateau region from surface wave dispersion; Bull. Seismol. Soc. Am. 57 235-248

Herren E 1987 Zanskar shear zone: Northeast-southwest extenstion within the Higher Himalayas (Ladakh, India); Geology 15 409-413

Hirn A and Sapin M 1984 The Himalayan zone of crustal interaction: Suggestions from explosion seismology; Ann. Geophysicae 2 123-130

Hirn A et al 1984a Crustal structure and variability of the Himalayan border with Tibet; Nature (London) 307 23-25

Him A, Jobert G, Wittlinger G, Xu Zhongxin and Gao Enyuan 1984b Main features of the upper lithosphere in the unit between the high Himalayas and the Yarlung Zhangbo Jiang suture; Ann. Geophysicae 2 113-117

Huestis S, Molnar P and Oliver J 1973 Regional $S_{n}$ velocities and shear velocity in the upper mantle; Bull. Seismol. Soc. Am. $63469-475$

Ibenbrahim A, Ni J and Gross R 1987 Three-dimensional crustal velocity structure beneath the Tarbela array, Pakistan; EOS Trans. Am. Geophys. Union 681373

Isacks B, Oliver J and Sykes L R 1968 Seismology and the new global tectonics; J. Geophys. Res. 73 5855-5900

Iwata S 1987 Mode and rate of uplift of the central Nepal Himalaya; Z. Geomorphol. NF $6337-49$ 
Iwata S, Sharma T and Yamanaka H 1984 A preliminary report on geomorphology of Central Nepal and Himalayan uplift; J. Nepal Geol. Soc. 4 141-149 (special issue)

Kaila K L, Kirshna V G, Choudhury $\mathrm{K}$ and Narain H 1978 Structure of the Kashmir Himalaya from deep seismic soundings; J. Geol. Soc. India 19 1-20

LeFort P 1975 Himalayas: the collided range. Present knowledge of the continental arc; Am. J. Sci. A275 $1-44$

LeFort P 1981 Manaslu leucogranite: A collision signature of the Himalaya, a model for its genesis and emplacement; J. Geophys. Res. 86 10545-10568

Lepine J-C, Hirn A, Pandey M R and Tater J M 1984 Features of the $P$ waves propagated in the crust of the Himalayas; Ann. Geophysicae 2 119-121

Lillie R J, Johnson G D, Mohammed Y, Zamin A S H and Yeats R S 1987 Structural development within the Himalayan foreland fold-and-thrust belt of Pakistan. In Sedimentary basins and basin-forming mechanisms (eds) C Beaumont and A J Tankard; Canadian Society of Petroleum Geologists, Memoir 12 379-392

Lyon-Caen H and Molnar P 1983 Constraints on the structure of the Himalaya from an analysis of gravity anomalies and a flexural model of the lithosphere; J. Geophys. Res. 88 8171-8191

Lyon-Caen $\mathrm{H}$ and Molnar P 1985 Gravity anomalies, flexure of the Indian plate, and the structure, support and evolution of the Himalaya and Ganga Basin; Tectonics 4 513-538

Marussi A 1964 Geophysics of the Karakorum Italian expeditions to the Karakorum (L2 and Hindu Kush) Sci. Rept. 2, 1, p. 242

Mathur L P and Evans P 1964 Oil in India. Sp. Brochure. Int. Geol. Congr. 22nd Session New Delhi 64-79

Mehta P I C 1980 Tectonic significance of the young mineral dates and rates of cooling and uplift in the Himalayas; Tectonophysics 62 205-212

Menke W H and Jacob K H 1976 Seismicity patterns in Pakistan and northwestern India associated with continental collision; Bull. Seismol. Soc. Am. 66 1695-1711

Molnar P 1984 Structure and tectonics of the Himalaya: Constraints and implications of geophysical data; Annu. Rev. Earth Planet. Sci. 12 489-518

Molnar P 1988 A review of geophysical constraints on the deep structure of the Tibetan Plateau, the Himalaya, and the Karakorum; Philos. Trans. R. Soc. London (in Press)

Molnar P and Chen W-P 1982 Seismicity and mountain building. In Mountain building processes (ed.) K Hsu (London: Academic Press)

Molnar P and Tapponnier P 1975 Cenozoic tectonics of Asia: Effects of a continental collision; Science 189 419-426

Molnar P, Chen W-P, Fitch T J, Tapponnier P, Warsi W E K and Wu R T 1977 Structure and tectonics of the Himalaya: A brief summary of geophysical observations. In Colloq. Int. C.N.R.S. Ecologie et Geologie de L'Himalaya vol. 2 269-294

Nakata T 1988 Active faults of the Himalaya of India and Nepal; Bull. Geol. Soc. Am. (in review)

Ni J and Barazangi M 1983 High-frequency seismic wave propagation beneath the Indian Shield, Himalayan arc, Tibetan Plateau, and surrounding regions: high uppermost mantle velocities and efficient $S_{\text {n }}$ propagation beneath Tibet; Geophys. J. R. Astron. Soc. $72665-689$

Ni J and Barazangi M 1984 Seismotectonics of the Himalayan collision zone: Geometry of the underthrusting Indian plate beneath the Himalaya; J. Geophys. Res. 89 1147-1163

Powell C M 1979 A speculative tectonic history of Pakistan and surroundings: some constraints from the Indian Ocean. In Geodynamics of Pakistan (eds) A Farah and K DeJong, (Quetta: Geol. Surv. of Pakistan) p. 5-24

Powell C M and Conaghan P J 1973 Plate tectonics and the Himalayas; Earth Planet. Sci. Lett. 20 1-12

Powell C M and Conaghan P J 1975 Tectonic models of the Tibetan Plateau; Geology 3 727-731

Pratt J H 1985 On the attraction of the Himalayan mountains, and of elevated regions beyond them, upon the plumb line in India; Philos. Trans. R. Soc. London 145 53-100

Qureshy M N 1969 Thickening of the basalt layer as a possible cause for the uplift of the Himalayas-a suggestion based on gravity data; Tectonophysics 7 137-157

Qureshy M N and Warsi W E K 1980 A Bouguer anomaly map of India and its relation to broad tectonic elements of the sub-continent; Geophys. J. R. Astron. Soc. 61 235-242

Seeber L and Armbruster J 1979 Seismicity of the Hazara Arc in northern Pakistan: Decollement versus basement folding. In Geodynamics of Pakistan (eds) A Farah and K A DeJong (Quetta: Geol. Surv. Pakistan) p. 131-142

Seeber $L$ and Armbruster J 1981 Great detachment earthquakes along the Himalayan arc and long-term 
forecasts; Earthquake prediction: An international review, Maurice Ewing Series 4, (eds) D W Simpson and P G Richards (Washington DC: Am. Geophys. Union) pp. 259-277

Seeber L, Armbruster $J$ and Quittmeyer R 1981 Seismicity and continental collision in the Himalayan arc. In Zagros. Hindu Kush, Himalaya, Geodynamic evolution; Geodynamics Series vol. 3 (Washington DC: Am. Geophys. Union) pp. 215-242

Seeber $\mathrm{L}$ and Gornitz V 1983 River profiles along the Himalayan arc as indicators of active tectonics; Tectonophysics 92 335-367

Sinha-Roy S 1982 Himalaya main central thrust and its implications for Himalayan inverted metamorphism; Tectonophysics 84 197-224

Stocklin J 1980 Geology of Nepal and its regional frame; J. Geol. Soc. London 137 1-34

Tapponnier P and Molnar P 1977 Active faulting and tectonics in China; J. Geophys. Res. 82 2905-2930

Verma R K and Prasad K A V L 1987 Analysis of gravity fields in the northwestern Himalayas and Kohistan region using deep seismic sounding data; Geophys. J. R. Astron. Soc. 91 869-889

Valdiya K S 1976 Himalayan transverse faults and folds and their parallelism with subsurface structures of north Indian plains; Tectonophysics 23 353-386

Valdiya K S 1980 The two intracrustal boundary thrusts of the Himalaya; Tectonophysics 66 323-348

Valdiya K S 1981 Tectonics of the central sector of the Himalaya. In Zagros, Hindu Kush, Himalaya, Geodynamic evolution Geodynamics Series, (eds) H Gupta and F Delany, vol. 3 (Washington DC: Am. Geophys. Union) and (Boulder: GSA) pp. 87-110

Vidal Ph 1978 Rb-Sr systematics in granite from central Nepal (Manaslu): Significance of the Oligocene age and high $87 \mathrm{Sr} / 86 \mathrm{Sr}$ ratio in Himalayan orogeny. Comment; Geology 6196

Wadia D N 1961 The Geology of India Third edn. (London: Macmillan)

Wadia Institute of Himalayan Geology, 1979 Annual Report 1978-79, Dehra Dun, India, 2-45

Wang J, Chen Z, Gui X, Xu R and Zhang Y $1981 \mathrm{Rb}-\mathrm{Sr}$ isotopic studies on some intermediate-acid plutons in southern Xizang. In Geological and ecological studies of Qinghai-Xizang Plateau (Beijing: Science Press) vol. 1, p. 515-520

Warsi W E K and Molnar P 1977 Gravity anomalies and plate tectonics in the Himalaya, Colloques Internationaux de CNRS, No. 268, Himalaya: Sciences de la Terre, Editions du Centre National de la Recherche Scientifique, Paris, 463-478

Xu R 1981 Vegetational changes in the past and the uplift of Qinghai-Xizang plateau. In Geological and ecological studies of Qinghai-Xizang Plateau (Beijing: Science Press) vol. 1, 139-144

Yeats R S and Hussain A 1987 Timing of structural events in the Himalayan foothills of northwestern Pakistan; Geol. Soc. Am. Bull. 99 161-176

Zeitler P K 1985 Cooling history of the N W Himalaya, Pakistan; Tectonics $4127-151$

Zeitier P K, Johnson N M, Naeser C W and Tahirkheli A K 1982 Fission-track evidence for Quaternary uplift of the Nanga Parbat region, Pakistan; Nature (London) 298 255-257 